NIHON REOROJĪ GAKKAISHI Vol. 25, No. 4, 221 222 (1997)

(C) 1997 The Society of Rheology, Japan

論文

Relationships between Morphology and Brittle Temperatures of

Polypropylene／Ethylene-Propylene Rubber Blends.

Kenji KAWABATA and Ei-ichi KAMEI

Polymer Laboratory, Corporate Research Development, Ube Industries, Ltd.,

1-12-32 Nishihonmachi, Ube, Yamaguchi, 755 Japan

\begin{abstract}
Morphology and brittle temperatures of seven Polypropylene(PP)/Ethylene-Propylene rubber(EPR) blends were investigated. Sizes and interparticle distances for dispersed EPR particles were measured. EPR concentrations in PP matrix phases were also evaluated. Based on these results and brittle temperatures for the blends, molecular mechamism of brittleductile transition for PP /EPR blend was discussed.
\end{abstract}

Key Words : Polypropylene/Ethylene-Propylene rubber/Blend/Interparticle distance/Brittle temperature/Glass transition temperature

\title{
ポリプロピレンエェレン・プロピレンラバーブレンドの 組織構造と脆化温度の関係
}

\author{
川端 健嗣*・亀井 衛一* \\ （原稿受理 : 1997年6月25日）
}

\section{1. 緒言}

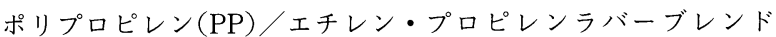
(EPR)ブレンドは, 工業的に最も大量に使用されている材料の 一つである. しかし，その物性は組成比が同じであってあ一様で なく, 使用するEPRに依存して大きく異なる，本研究ではこの 理由を明確にするために, ブレンドの組織構造と脆化温度の関係 について検討した.

\section{2. 試 料}

Table I に，成分ポリマーとして用いたPP抢よびEPRの重 量分率で表したエチレン含量 $\mathrm{C}_{\mathrm{E}}, 230^{\circ} \mathrm{C}$ におけるメルトフローイ ンデックスMFIおよびガラス転移温度 $T_{g}$ を示した. ブレンド試料 は，東洋精機社製ブラベンダー型小型二軸混練機により, PP と7

Table I Ethylene contents, melt flow indexes and glasstransition temperatures for the component polymers employed.

\begin{tabular}{crrrrrrrr}
\hline & PP & EPR-1 & EPR -2 & EPR -3 & EPR -4 & EPR -5 & EPR -6 & EPR -7 \\
\hline $\mathrm{C}_{\text {E }}$ & - & 45.1 & 36.2 & 29 & 25.1 & 25 & 22.1 & 17.7 \\
$\mathrm{MFI}$ & 250 & 1.9 & 3.8 & 5.9 & 1.6 & 2.2 & 4.3 & 7.6 \\
$\mathrm{Tg}\left({ }^{\circ} \mathrm{C}\right)$ & 5.8 & -39.7 & -29.7 & -26.6 & -19.9 & -19.7 & -18.5 & -15.3 \\
\hline
\end{tabular}

*宇部興産株式会社 研究開発本部 高分子研究所 厂755 山口県宇部市西本町1丁目12番32号
種のEPRの各組合せについてそれぞれ PP/EPR $=75 / 25$ の重量比 で $180^{\circ} \mathrm{C}$ で熔融混練して調製された。

\section{3. 結果と考察}

\section{1 ブレンドの組織構造}

ブレンド試料は，ほとんど分散粒子が観察されないPP／EPR一 7の系を除いて，いずれもEPRが島状に分散した典型的な海島構

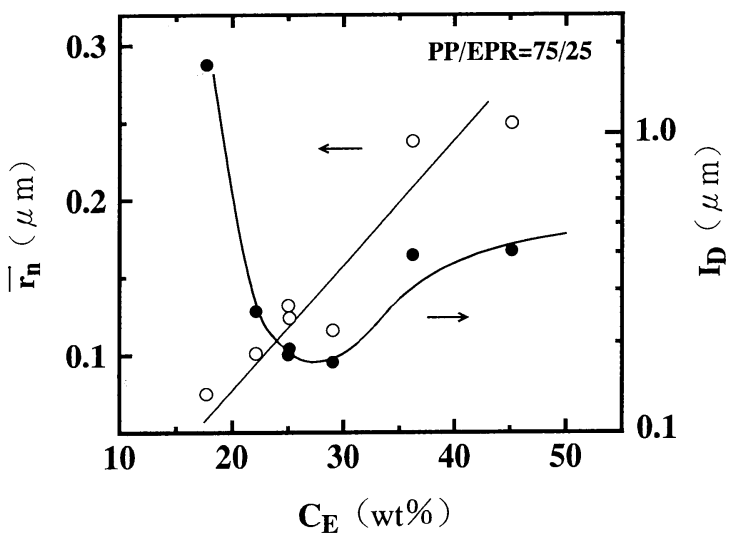

Fig. 1 Plots of radii of dispersed particles and interparticle distaneces for seven blend samples against ethylene content for their component EPRs. 
造を有する. ブレンド試料のこのような組織構造を定量的に表す ために, Fig. 1にはTEM像の画像解析より得た分散粒子の数平 均半径 $\bar{r}_{\mathrm{n}}$ および分散粒子壁間距離 $I_{\mathrm{D}}$ を, 成分EPRのエチレン含量 に対してプロットした．ただし， $I_{\mathrm{D}}$ は向かい合う分散粒子の平均 最短界面間距離である. 分散粒子の大きさはEPRのエチレン含 量の減少とともに単調に減少するのに対して， $I_{\mathrm{D}}$ はエチレン含量 約 $27 \%$ で極小值を有することが分る.この低エチレン含量領域 での $I_{\mathrm{D}}$ の増大は, PPへのEPRの溶解量の増加に伴う分散粒子数 の減少によるものと考えることができる，この結果は，ブレンド の物性の理解のためにはPPへのEPRの溶解量を知る必要がある ことを示唆している.

本研究では, PPへのEPRの溶解量を動的損失弾性率 $E$ ”の温度 分散曲線から求めたPPマトリックス相の $T_{g}$ に相溶系ブレンドの $T_{g}$ の組成依存性を表すFoxの経験式1を適用して評価した。なお， $\mathrm{EPR}$ 分散相の $T_{g}$ はブレンド前のEPRのそれと同じであった。

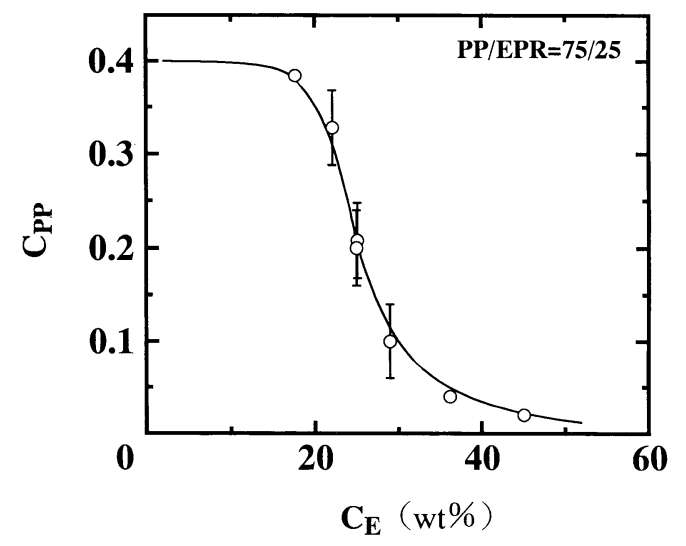

Fig. 2 EPR concentrations in amorphous region of PP matrix phase for seven blend samples plotted against ethylene content for their component EPRs.

Fig. 2にこのようにして求めたPPマトリックス相に打けるEPR の濃度 $C_{P P}$ を, 成分EPRのエチレン含量に対してプロットした。 $C_{P P}$ はPP非晶相におけるEPRの重量分率で表されており, PPの 結晶度を $50 \%$ 之仮定すればEPRの全てがPPに溶解した際に $C_{P P}=0.4$ となる，図から明らかなように，PPへの溶解量は成分 EPRのエチレン含量が20３0\%の領域で急激に増加し，20\%以 下の領域ではほぼ添加EPRの全量となる。すなわち, 本研究の ブレンド系は成分EPRのエチレン含量が20～30\%の領域で非相 溶系から相溶系へ転移することが分る.

\section{2 ブレンドの脆化温度}

応力ーひずみ特性の温度依存性から評価したブレンド試料の脆 化温度 $\mathrm{T}_{\mathrm{B}}$ を成分EPRのエチレン含量に対してFig. $3 に$ ス゚ロット した，比較のため，同じ図にEPR分散相の $T_{g}$ および添加した $\mathrm{EPR}$ 全量がPPに溶解した場合のPPマトリックス相の $T_{g}$ と成 分EPRのエチレン含量との関係をそれぞれEPRおよびPP／EPR と添字した破線で示した. 図の左右の縦軸は, その值は異なるが スケールの大きさは同じにしてある。図からプロットは，成分 EPRのエチレン含量が20〜 40\%の領域で添字EPRの破線上に, また $20 \%$ 以下の領域で添字PP／EPRの破線上にあることが分る. この結果はブレンドの $\mathrm{T}_{\mathrm{B}}$ を決定する上での支配因子が成分 $\mathrm{EPR}$

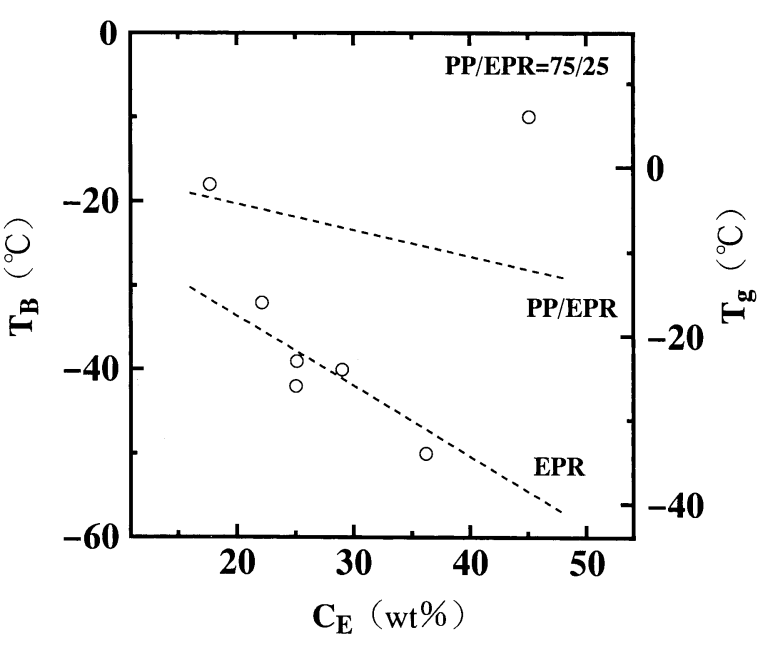

Fig. 3 Brittle temperatures for seven blend samples plotted against ethylene content for their component EPRs. Two broken lines suffixed by EPR and PP / EPR denote dependence of glass transition temperatures for EPR and PP matrix phase which contains total amount of added EPR on ethylene content, Respectively.

のエチレン含量が20４0\%の領域ではEPR分散相の，それ以外 の領域ではPPマトリックス相の $T_{g}$ であることを示唆する. $\mathrm{Wu}^{2.3)}$ は非相溶系ブレンドの脆性一延性転移がゴム分散相の $I_{\mathrm{D}}$ によっ て特徵づけられ， $I_{\mathrm{D}}$ が臨界值より小さければ，試料片は延性的に 破壊することを報告している．このWuらの結果およびFig. 3か ら, 脆化温度の発現機構として次の機構を考えることができる.

成分EPRのエチレン含量が $40 \%$ 以上の領域では，ブレンドは ほぼ非相溶系であり， $I_{\mathrm{D}}$ が臨界距離より大きいために分散粒子は 応力集中体として有効に作用しない，その結果， $T_{\mathrm{B}}$ はPPマトリッ クス相のガラス転移温度に支配されることになる。一方，成分 $\mathrm{E}$ PRのエチレン含量が20〜 40\%の領域では，ブレンドは部分溶解 系であり， $I_{\mathrm{D}}$ が臨界距離より十分小さくなり，分散相のほぼ全て が応力集中体として有効に働く，すなわち，臨界壁間距離を満足 するこの領域での $T_{\mathrm{B}}$ は，EPR分散相とPPマトリックス相との間 に弾性率差がなくなりEPR分散相が応力集中体として作用しな くなる温度，つまり成分EPRの $T_{\mathrm{B}}$ に支配されることになる。そ れゆえに，この領域での $T_{\mathrm{B}}$ は成分EPRの $I_{\mathrm{D}}$ の低下とともに低下 する。.さらに，成分EPRのエチレン含量が $20 \%$ 以下と低い領域 では，ブレンドが相溶系へと転移するために応力集中に有効な分 散粒子が消失し， $T_{\mathrm{B}}$ はPP $/ \mathrm{EPR}$ 混合相の $I_{\mathrm{D}}$ によって支配される ようになる。

このように, PP／EPRブレンドに発現する物性の多様性は, 成分EPRの共重合組成に基づくブレンドの多様な組織構造に起 因すると結論づけることができる.

\section{文献}

1) Fox T. G., Bull. Am. Phys. Soc., 1, 123(1956).

2) Wu S., Polymer, 26, 1855(1985).

3 ) Wu S., Polymer, 29, 2170(1988). 